Arhe XVIII, 36/2021

UDK 050:1 Praxis

141.852

331.107

DOI https://doi.org/10.19090/arhe.2021.36.275-294

Originalni naučni rad

Original Scientific Article

MILOŠ JANKOVIĆ ${ }^{1}$

Univerzitet u Beogradu, Institut za filozofiju i društvenu teoriju

\title{
POGLEDI NA DIREKTNU DEMOKRATIJU I SAMOUPRAVLJANJE IZ PERSPEKTIVE ČASOPISA PRAXIS ${ }^{2}$
}

Sažetak: U radu se analiziraju tekstovi jugoslovenskih autora časopisa Praxis tokom jedanaestogodišnje produkcije i daje se prikaz različitih pogleda na direktnu (delegatsku, participativnu) demokratiju i radničko, odnosno društveno, samoupravljanje. Na osnovu različitih razumevanja normativnih modela direktne demokratije i samoupravljanja identifikuju se četiri glavne linije kritike koje se mogu okarakterisati kao: 1) etatizam, 2) nedovoljna demokratizacija, 3) neintegralnost samoupravljanja i 4) tržišna orijentacija. Kritike se, s jedne strane, međusobno dopunjuju, dok su s druge strane postavljene jedne nasuprot drugih.

Ključne reči: direktna demokratija, samoupravljanje, Praxis

\section{1. ČEMU DANAS PRIČA O DIREKTNOJ DEMOKRATIJI I SAMOUPRAVLJANJU?}

U ovom radu pokušaću da izložim pogled(e) na demokratiju i samoupravljanje u socijalističkoj Jugoslaviji iz perspektive časopisa Praxis. Utemeljen na ideji „kritike svega postojećeg“, Praxis nam pruža kritički pogled na zbivanja u Jugoslaviji kroz vizuru levih političkih i

\footnotetext{
${ }^{1}$ E-mail adresa autora: milos.jankovic@instifdt.bg.ac.rs

${ }^{2}$ Ovaj rad je realizovan uz podršku Ministarstva prosvete, nauke i tehnološkog razvoja Republike Srbije prema Ugovoru o realizaciji i finansiranju naučnoistraživačkog rada.
} 
ideoloških uverenja. U vreme kada gubi svoju kritičnost jer postaje državna ideologija, autori okupljeni oko ovog časopisa pokušavaju rehabilitovati marksizam stavljajući akcenat na njegovu humanističku i nedogmatsku dimenziju. Iako im je zajedničko bilo odbacivanje kako ekonomskog, tako i istorijskog determinizma, „[̌s]kola nije imala jedinstvenu filozofsku i sociološku koncepciju. Njene predstavnike je povezivala zajednička namjera da u duhu Marksove filozofije, njemačke idealističke filozofije, kao i savremenih filozofskih tendencija na Zapadu kritički promišljaju bitne probleme savremenog svijeta, probleme teorije i prakse socijalizma, kao i da tragaju za putevima humanizacije života i izgradnje humanijeg modernog društva. “3 Zato je preciznije reći da rad ispituje različite poglede na probleme demokratije i samoupravljanja $u$ socijalističkoj Jugoslaviji.

U vreme kada se na globalnom nivou suočavamo sa krizom neoliberalnog ekonomskog i političkog poretka, čini mi se korisnim ponovno preispitati ideje direktne (ili u nekim interpretacijama participativne) demokratije i radničkog (ili šire, društvenog) samoupravljanja.

Ovaj poduhvat moguće je izvesti na mnogo načina. $\mathrm{Na}$ normativnom nivou moguće je ispitati da li participativniji oblici demokratije imaju veću intrinsičnu ili instrumentalnu vrednost od uskog Šumpeterovog (Joseph Schumpeter) modela. Na ekonomskom nivou, značajni bi bili uvidi u odnos efikasnosti proizvodnje i vlasničke strukture. $\mathrm{Na}$ radno-pravnom nivou, potentno je analizirati uticaj društvene klime na sindikalnu borbu i moć radnika. U ovom radu izabrao sam drugačiji pristup. Kroz analizu tekstova objavljenih u časopisu Praxis, pokušaću da ukažem na potencijalne probleme koji se mogu javiti ukoliko odlučimo da ponovo oživimo pomenute koncepte. Rečima ekonomiste Majkla Lebovica (Michael Lebowitz): „moramo biti spremni za borbu sa realnim problemima radničkog samoupravljanja."4 Čini mi se da nam autori koji su istinski verovali u ideju direktne demokratije i

${ }^{3}$ Milenko A. Perović, „Praxis-filozofija“, Arhe 11 (22): 124.

${ }^{4}$ Michael Lebowitz, Build it Now: Socialism for the Twenty-First Century (New York: Monthly Review Press, 2006), 74. 
samoupravljanja, a koji su istovremeno i pisali u vreme (barem načelnog) pokušaja njihove implementacije, mogu pružiti značajne uvide $\mathrm{u}$ realne probleme njihovog funkcionisanja i neželjene posledice izostanka želje političke elite da se odrekne dela svoje moći.

Pre nego što krenem, važno je istaći nekoliko metodoloških napomena i ograničenja. Prvo, razmatrao sam sve brojeve časopisa Praxis koji su objavljeni na srpsko-hrvatskom jeziku. ${ }^{5}$ Drugo, kao jedinicu analize odabrao sam samo one tekstove koji su u svom naslovu sadržali ili reč „,demokratija“ ili reč „samoupravljanje“ u bilo kom obliku, a koje su napisali jugoslovenski autori. Takvih tekstova ukupno je bilo 23 .

Prvo važno ograničenje ovako odabranog metodološkog pristupa je što iz analize izostaju svi oni tekstovi koji se bave pitanjima (direktne) demokratije i samoupravljanja, a koji u svojim naslovima ne ekspliciraju ove reči. Kako je građa izuzetno obimna, te je u 11 godina koliko je časopis izlazio objavljeno 59 brojeva na ukupno 8350 stranica, bilo je nemoguće za potrebe ovog rada upustiti se u sveobuhvatnu analizu svih tekstova. $^{6}$

Drugo, autori koji su pisali za časopis uporedo su objavljivali veliki broj knjiga i članaka van samog časopisa. Preciznija i opsežnija analiza morala bi obuhvatiti i te radove, imajući u vidu da su članci u Praxisu često samo dopune njihovih uvida objavljenih na drugim mestima. Takva analiza bi u značajnijoj meri uzimala u obzir kontekst $u$ kome su tekstovi nastajali.

U vezi sa tim je i treće ograničenje. Ton i oštrina kritike nisu bili isti svih jedanaest godina i često su zavisili od političkih okolnosti i ograničenja slobode govora. Ovaj aspekt takođe je ostao van domena analize.

\footnotetext{
${ }^{5}$ Jedino je časopis broj pet izdanja iz 1971. godine ostao van razmatranja, jer ga iz nekog razloga nema u celokupnoj digitalizovanoj arhivi.

6 Ante Lešaja, Praksis orijentacija, časopis Praxis $i$ Korčulanska ljetna škola:(građa) (Beograd: Rosa Luxemburg Stiftung Southeast Europe, 2014), 121.
} 
I pored navedenih ograničenja, smatram da nam odabrani pristup pruža značajan uvid u Praxisov(e) $\operatorname{pogled}(\mathrm{e})^{7}$ u vezi sa pitanjima (direktne) demokratije i samoupravljanja. Nakon ovih uvodnih napomena sledi pojednostavljen prikaz jugoslovenskog konteksta, a potom prelazim na same tekstove. Na kraju dajem zaključna razmatranja.

\section{JUGOSLOVENSKO SAMOUPRAVLJANJE, SOCIJALISTIČKA DEMOKRATIJA I PRAXIS}

Samoupravljanje je u socijalističkoj Jugoslaviji uvedeno 1950. godine. Pod parolom „Fabrike radnicima“ Tito je 27. juna „doneo osnovni zakon po kojem radnički kolektivi upravljaju državnim

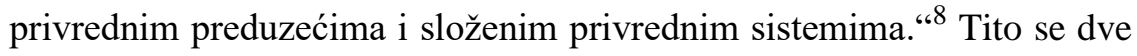
godine ranije razišao sa Staljinom te je bilo ,potrebno na takav način raskrstiti sa prethodnim periodom (1945-1950) da taj raskid s totalitarnom partijskom državom bude legitiman u okvirima boljševičkog nasleđa, s jedne, i da ne ugrozi partijski monopol, s druge strane. “9 Pored toga, Tito je želeo krenuti trećim putem i svideti se „radikalnoj globalnoj publici, osobito u zemljama u razvoju. “10 $\mathrm{Na}$ kraju, Partija je morala i obnoviti političku mobilizaciju. ${ }^{11}$

Činilo se da Marksova (Karl Marx) ideja o odumiranju države, obučena $u$ veo radničkog samoupravljanja, ispunjava sve navedene

\footnotetext{
${ }^{7}$ Još jednom napominjem da smatram su u Praxisu izloženi različiti pogledi na društvenu stvarnost i da nije u pitanju koherentna grupa. Slično tvrdi i Božidar Jakšić kada kaže da „ne postoji tako nešto kao praxis-grupa, filozofi prakse ili praxis filozofi koji bi imali jedinstvenu filozofsku ili društveno-teorijsku orijentaciju.“ Božidar Jakšić, „Praxis Gaje Petrovića“, Filozofija i društvo 33 (2007): 73.

8 Ričard Dž. Krempton, Balkan posle Drugog svetskog rata, prev. Ksenija Todorović (Beograd: Clio, 2003), 165-166.

9 Laslo Sekelj, Jugoslavija, struktura raspadanja (Beograd: Izdavačko preduzeće Rad, 1990), 9.

10 Vladimir Unkovski-Korica, „Samoupravljanje, razvoj i dug: uspon i pad 'jugoslovenskog eksperimenta'“, U Dobro došli u pustinju postsocijalizma, Ur. Srećko Horvar i Igor Štiks (Zaprešić: Fraktura, 2015), 47.

${ }^{11}$ Ibid., 49.
} 
zahteve. Usvojena je nova linija društvenog kretanja, a „Boris Kidrič izložio je model društveno-ekonomskih odnosa i privrednog sistema koji je trebao biti“ u skladu sa tom linijom. ${ }^{12}$ Tako je započelo doba jugoslovenskog samoupravnog socijalizma.

Nije, međutim, bilo dovoljno samo načelno ustupanje fabrika radnicima. Promenjena paradigma uključivala je i novo razumevanje države, „koja se sada tretira samo kao sredstvo, pa i nužno zlo i u čijem se monopolističkom položaju vidi glavna i gotovo jedina opasnost po radničku klasu i društvo u celini." ${ }^{\text {"13 }} \mathrm{U}$ vezi sa tim morao se promeniti i položaj državnih organa vlasti i dodeliti veća autonomija lokalnim telima. ${ }^{14}$ Bilandžić ovako sažima pravac političkih promena:

„Tako je Zakon o narodnim odborima znatno proširio autonomiju lokalnih organa. Oni su dobili šira prava u poslovima od neposrednog interesa za komunalni, socijalni i kulturni razvitak lokalne zajednice $i$ u drugim poslovima koje obavljaju. Ukinut je hijerarhijski odnos centralnih prema lokalnim organima. Jača uloga savjeta i komisija narodnih odbora, ukidaju se izvršni odbori narodnih odbora da bi se ojačala uloga plenuma (to jest izabranih odbornika), uvodi se institucija lokalnog referenduma, afirmiraju se zborovi birača i slično. "ls

Kao jedan od završnih koraka ovog društvenog, političkog i ekonomskog preobražaja, na Šestom kongresu Komunističke partije Jugoslavije održanom 1952. godine u Zagrebu, na Titov predlog, Partija menja ime u Savez komunista Jugoslavije. ${ }^{16}$

Ipak, i nakon velikih promena, sva moć ostala je u rukama partijskog vrha. Ogroman deo dohotka i dalje je bio van domašaja

${ }^{12}$ Dušan Bilandžić, Historija Socijalističke Federativne Republike Jugoslavije (Zagreb: Školska knjiga, 1978), 172.

${ }^{13}$ Ibid., 177.

${ }^{14}$ Ibid.

15 Ibid.

16 Domagoj Štefančić, „Promjena naziva Komunističke partije Jugoslavije u Savez komunista Jugoslavije“, Radovi: Radovi Zavoda za hrvatsku povijest Filozofskoga fakulteta Sveučilišta u Zagrebu 39, no. 1 (2007): 260. 
radnika, a državni aparat je „enormno narastao u periodu 1952-1964. od 119 na 188 hiljada." ${ }^{17}$

U narednih par decenija izvršeno je nekoliko političkih i privrednih reformi, ali radnici ni iz jedne nisu izlazili kao pobednici. Imali su sve manje moći, došlo je do produbljivanja nejednakosti, a samoupravljanje je na kraju izgubilo svoj pokretački potencijal.

U ovakvim okolnostima, 1964 godine, nastaje časopis Praxis. Autori Praxisa pretežno su dolazili iz oblasti filozofije i sociologije. Koliko god da su se bavili akademskim radom, filozofija za njih nije bila samo „akademska disciplina“, već je ,interpretirana kao nužno intervenirajuća znanost koja aktivno i neposredno djeluje u društvu i društvenim zbivanjima.“"18 Upravo zbog te želje autora da društveno deluju, Praxis je ukinut 1974. godine uskraćivanjem sredstava, čime je okončan jednodecenijski život časopisa Korčulanske letnje škole. ${ }^{19}$

\section{DEMOKRATIJA I SAMOUPRAVLJANJE IZ VIZURE ČASOPISA PRAXIS}

Autori časopisa Praxis ukazuju na različite probleme sa kojima se susretalo jugoslovensko društvo. Pišu o brojnim temama i iz različitih perspektiva. Koliko god ih neki interpretatori opisivali kao jedinstvenu Praxis grupu, njihove kritike ne samo da ne mogu formirati jedan koherentan pogled, već su često međusobno suprotstavljene. U nastavku ću izložiti četiri tipa različitih kritika koje se istovremeno međusobno dopunjuju, ali i protivreče jedna drugoj. Ugrubo ih možemo okarakterisati kao: 1) etatizam, 2) nedovoljna demokratizacija, 3) neintegralnost samoupravljanja i 4) tržišna orijentacija.

\footnotetext{
${ }^{17}$ Sekelj, Jugoslavija, struktura raspadanja, 11-12.

${ }^{18}$ Boris Kanzleiter i Krunoslav Stojaković, „Predgovor“, U Praxis: Društvena kritika $i$ humanistički socijalizam, Ur. Dragomir Olujić Oluja i Krunoslav Stojaković (Beograd: Rosa Luxemburg Stiftung Southeast Europe, 2012), 2.

${ }^{19}$ Predrag Matvejević, „Requiem za jednu ljevicu“, U Praxis: Društvena kritika $i$ humanistički socijalizam, Ur. Dragomir Olujić Oluja i Krunoslav Stojaković (Beograd: Rosa Luxemburg Stiftung Southeast Europe, 2012), 15.
} 


\subsection{Etatizam}

Jedan deo autora smatra da je osnovni problem jugoslovenskog društva izuzetno jak uticaj države. Polazeći od Marksovog koncepta odumiranja države, koji je nakon 1950. godine postao okosnica jugoslovenske socijalističke ideologije, ovi autori sugerišu da se po tom pitanju uradilo jako malo i da proces deetatizacije nije sproveden $u$ dovoljnoj meri. Tako Cvjetičanin navodi kako je jugoslovensko socijalističko društvo i dalje ,ispod nivoa općeg modela marksističke teorije o odumiranju države.“ ${ }^{\text {(20 }}$

Kasnijih godina ova kritika postaje sve upečatljivija. Otvoreno se tvrdi da je Jugoslavija odustala od načela odumiranja države i da je tu ideju svela na „puku marksističku frazeologiju.“21 Žvan se izrazito protivi ideji etatističkog paternalizma kojom se opstanak „etatističke strukture na višim nivoima organizacije društva“ pravda potrebama samog samoupravljanja. ${ }^{22}$ Iz te vizure opstanak države je neophodan jer država mora „1. Da brani slobodni prostor samoupravljanja od svih antisamoupravnih i antisocijalističkih posezanja. 2. Da arbitrira u rješavanju društvenih proturječnosti kad se one ne mogu riješiti na temelju tzv. (?) društvenog i samoupravnog dogovora. 3) Da podstiče ravnomjerniji i pravedniji razmještaj proizvodnih snaga na teritoriju naše republike.“23

Žvan je sumnjičav prema sva tri zahteva koja se upućuju državi u ime samoupravljanja. Prvo, on tvrdi da je najveći protivnik samoupravljanja upravo sama država, te je nerazumno očekivati da će država samoupravljanje zaštiti od sebe same. Drugo, Žvan se pita zašto bi država bila bolji arbitar od samih proizvođača, te zašto se protivrečnosti ne bi mogle prevazilaziti društvenim dogovaranjem. I treće, on upozorava da se država u ranijem periodu pokazala kao neko ko

${ }^{20}$ Veljko Cvjetičanin, „Odumiranje države kao proces razvoja samoupravljanja u Jugoslaviji“, Praxis-Jugoslovensko izdanje 4-6 (1966): 749.

21 Antun Žvan, „Etatistički paternalizam ili samoupravljanje“, PraxisJugoslovensko izdanje 6 (1971): 939.

22 Ibid., 941.

${ }^{23}$ Ibid., 943. 
ne uspeva da na adekvatan način vrši preraspodelu. Zato, smatra Žvan, nema ni jednog dobrog razloga prikloniti se poziciji etatističkog paternalizma i sprečiti proces odumiranja države. ${ }^{24}$

Iako Žvan daje jake argumente protiv etatizma, ostaje nejasno da li kao alternativu nudi uspostavljanje delegatske direktne demokratije, ili neku vrstu tržišnog, prudonističkog anarholiberalizma. U tekstu ima elemenata koji mogu sugerisati i jedno i drugo. U prilog prvom pogledu leži njegova kritika implementiranog modela radničkog samoupravljanja. Ovako Žvan: „Pokazalo se, naime, da radničko samoupravljanje razmrvljeno, ograničeno i sabijeno u tvorničke zidove ne može uspješno kontrolirati više nivoe društvene organizacije i utjecati na njihov rad.“25 Naglašavanjem odsustva mogućnosti radnika da utiču na „više nivoe društvene organizacije“, demokratizacija, a ne ukidanje viših društvenih instanci, implicitno se nameće kao normativni ideal.

Sa druge strane, u prilog druge interpretacije stoji njegova zapitanost zašto „država, a ne udruženi proizvođači (privreda), treba da brine o ravnomjernom razvoju ekonomije. ${ }^{\text {'26 }} \mathrm{U}$ ovim rečima možemo prepoznati određene elemente tržišnog fundamentalizma $i$ vere $u$ privrednu samoregulaciju.

Za razliku od Žvana, Andrija Krešić odbija svaku mogućnost demokratizacije i zahteva striktnu deetatizaciju. Mada nigde eksplicitno ne pominje Prudona, čini se da Krešić zagovara upravo prudonistički model samoupravljanja bez države. Za njega nije važno da se državna vlast demokratizuje, jer, kako navodi ,[s]amoupravljanje po definiciji negira svaku vanjsku, tuđu ili otuđenu prevlast, te i svaku državnost (despotsku i demokratsku, nacionalnu i nadnacionalnu, prerevolucionarnu i postrevolucionarnu. “27 Krešić negira čak i mogućnost demokratskog društvenog ugovora kao nedržavnog načina „usklađivanja interesa, osobito u ekonomskoj oblasti kao korektiv raznih

\footnotetext{
${ }^{24}$ Ibid., 943-947.

${ }^{25}$ Ibid., 944.

${ }^{26}$ Ibid., 947.

27 Andrija Krešić, „Proizvodni princip samouprave“, Praxis-Jugoslovensko izdanje 6 (1971): 828.
} 
anomalija tržišne privrede.“28 Smatra da „sama preporuka ima za pretpostavku nesklad interesa, znači više terapiju nego preventivu, a u ekonomskoj oblasti predstavlja vanekonomsku intervenciju. “29

Kao što vidimo na primeru zahteva za deetatizacijom koji se temelji na zvaničnoj ideološkoj mantri o odumiranju države, autori na različite načine interpretiraju značenje i realizaciju ove ideje. Ono u čemu se slažu jeste da država ne samo da nije odumrla, već je i dalje veoma jaka, što partijskom vrhu omogućava dominaciju nad radništvom.

\subsection{Nedovoljna demokratizacija}

Drugo važno pitanje jeste pitanje demokratije i demokratizacije. Mada deetatizacija ima dodirnih tačaka sa demokratizacijom, očigledno je da su u pitanju različiti procesi. Iako je rečeno da autori Praxisa ne daju koherentan pogled na svet, čini se da se dobrim delom slažu po pitanju razumevanja demokratije. Velika većina odbacuje predstavnički model kao neodgovarajući. Rečima Ljubomira Tadića: „demokratija nije isto što i parlamentarizam i reprezentativni sistem koji je stvorila konzervativna buržoazija.“30

Da bi se razumele kritike i predlozi autora Praxisa, važno je istaći šta za njih predstavlja demokratija. Svetozar Stojanović daje jednu marksističku definiciju: „Demokratija je učešće maksimalnog broja pripadnika društvene zajednice $\mathrm{u}$ odlučivanju o stvarima od opšteg značaja.“31 Bez obzira što je njegova definicija maksimalistička, on smatra da je o demokratiji korisnije razmišljati u kontinualnom pogledu, te razlikovati zajednice koje su više ili manje demokratske. U vezi sa tim, daje tri elementa demokratije i sugeriše da se procena može vršiti: „1) prema broju pripadnika koji učestvuju, 2) prema stepenu učešća i 3)

\footnotetext{
${ }^{28}$ Ibid., 829.

${ }^{29}$ Ibid.

${ }^{30}$ Ljubomir Tadić, „Moć, elite i demokratija“, Praxis-Jugoslovensko izdanje 1-2 (1970): 74.

31 Svetozar Stojanović, „Sloboda i demokracija u socijalizmu“, PraxisJugoslovensko izdanje 2 (1964): 206.
} 
prema načinu učešća (posrednom i neposrednom). Prema tim razlikama određivao bi se stepen demokratičnosti jedne društvene zajednice.“ ${ }^{\text {32 }}$

Polazeći od ovakve koncepcije demokratije, Stojanović tvrdi da je priča o višepartizmu i partijskim sistemima neopravdano „tabuisana tema u gotovo svim socijalističkim zemljama،“33 Koliko god se protivio buržoaskoj predstavničkoj demokratiji, ističe da se ne sme ,zaboraviti da je izbor između više kandidata, makar i pripadnika monopolističkih grupa, ipak izbor, ma koliko sveden na minimum. Zato se može reći da je prelaz u socijalizam pod ostalim jednakim uslovima demokratskiji ako se vrši kroz višepartijski sistem. ${ }^{\text {“34 }}$

Vukasović na praktičnom primeru pokazuje implikacije monopolističke pozicije Partije:

„Već mjesecima svakodnevno govorimo o kritičnom položaju u kome su se našle $i$ još uvijek se nalaze kultura, prosvjeta, školstvo. Ukazujemo na teške posljedice koje će otuda slijediti. Cijelo naše društvo se izjasnilo da ove djelatnosti treba postaviti u ravnopravan položaj s ostalim djelatnostima, a odgovor je — preraspodjele nema. Tko tu dakle upravlja? “35

Stojanović na drugom mestu daje institucionalne obrise delegatske demokratije koja bi bila kompatibilna sa razvojem društvenog samoupravljanja. U tom pogledu smatra nužnim „konstituisanje vertikalnih asocijacija samoupravnih grupa, izrastanje predstavničkih tela odozdo, stavljanje pod njihovu kontrolu ne samo svih državnih organa nego i čitavog društvenog života, bitno demokratizovanje i prilagođavanje političkih organizacija (pre svega komunističke) takvom sistemu. “36

\footnotetext{
32 Ibid.

${ }^{33}$ Ibid., 211.

34 Ibid.

${ }^{35}$ Ante Vukasović, „Mogućnosti i granice samoupravljanja u kulturi i prosvjeti“, Praxis-Jugoslovensko izdanje 1-2 (1967): 130.

${ }^{36}$ Svetozar Stojanović, „Društveno samoupravljanje i socijalistička zajednica“, Praxis-Jugoslovensko izdanje 5-6 (1967): 684.
} 
Demokratija se $\mathrm{u}$ Praxisu obično promišlja $\mathrm{u}$ kontekstu sveobuhvatnog, integralnog koncepta samoupravljanja, što nije neobično ukoliko se prisetimo Stojanovićeve definicije. Ovo će biti tema narednog potpoglavlja. Pre nego što ga započnem, smatram da je na kraju ovog dela važno zasebnu pažnju posvetiti kritici koju izlaže Veljko Rus. Za razliku od ostalih autora, on problemu prilazi iz sociološke perspektive koja se znatno razlikuje od svega do sad navedenog.

Rus polazi od empirijskih problema koji su se pojavili u jugoslovenskom društvu poput štrajkova, studentskih borbi, emigracije, nezaposlenosti, nacionalnog pitanja. Smatra da uzrok ovih problema leži u odbijanju da se prepozna legitimnost društvenog konflikta. Rus, dakle, kritikuje polazna ideološka načela i zalaže se za njihovu revalorizaciju.

Ukratko, njegova kritika se može sažeti na sledeći način. U Jugoslaviji se pošlo od Marksove pretpostavke da izvor neravnomerne raspodele moći leži u privatnom vlasništvu. Pozivajući se na određena empirijska istraživanja, Rus tvrdi da je ovo pogrešna pretpostavka i smatra da, prateći Vebera (Max Weber), veći uticaj ima podela rada. Pošto u okvirima samoupravljanja nije nestala podela rada, nije nestala ni neravnomerna raspodela moći $\mathrm{u}$ okviru radnih organizacija. Posledično, usled neravnomerne raspodele moći stvaraju se različiti interesi.

Samoupravljanje je zamišljeno kao prevazilaženje suprotstavljenih interesa u radnim kolektivima. Ideja je da će, nakon što fabrike budu predate radnicima, nestati sve suprotnosti. Problem je, tvrdi Rus, što se u radnim kolektivima težilo disperziji aktivne moći odlučivanja, a ne pasivne moći kontrole. Široka aktivna moć odlučivanja bez adekvatne kontrole stvorila je različite suprotstavljene grupe u okviru preduzeća, gde je najjača grupa, koju možemo prepoznati kao tehno-birokrate, svoje interese istakla kao zajedničke interese čitavog kolektiva. Sa druge strane, interesi radnika nisu mogli legitimno da se iskažu, jer država nije priznavala legitiman konflikt. Svaki sukob gušila je kao kontrarevolucionaran, te su radnici postajali sve pasivniji, a ideja samoupravljanja izgubila je svoju pokretačku snagu.

Tako je radničko samoupravljanje postalo paradigma nelegitimnosti sukoba svake vrste i na svim poljima. Rus smatra da 
konflikti ne moraju biti suprotstavljeni ideji socijalizma. Pitanje je interpretacije kako merimo zasluženi dohodak prema radu, koje vrste nejednakosti su dopuštene i slično. Zato predlaže da se izvrši revalorizacija osnovnih vrednosti, da se prizna legitimnost društvenih neslaganja, da se prepoznaju i institucionalizuju mehanizmi pregovaranja, te da se proširi pasivna moć radnika, umesto što se uporno teži povećanju njene aktivne moći. Ovo bi bili koraci ka većoj stabilnosti i demokratičnosti i samoupravljanja i društva u celini. ${ }^{37}$

U Rusovoj sveobuhvatnoj analizi jednog konkretnog problema kriju se brojni elementi koje i ostali autori identifikuju kao probleme demokratskog deficita u Jugoslaviji. Tako Vukosavić pokreće pitanja kontrole i dijaloga ${ }^{38}$, Stojanović navodi štrajk kao još jednu tabuisanu temu ${ }^{39}$, a u kasnijim radovima se osvrće i na Partiju u kojoj se „svim fundamentalnim konfliktima poriče socijalistički karakter.“40 Ipak, Rusova temeljna analiza uspeva da obuhvati celovitost problema praveći jasne veze među navedenim elementima.

\subsection{Neintegralnost samoupravljanja}

Demokratija i samoupravljanje u socijalističkoj Jugoslaviji često su posmatrani kao neodvojivi koncepti. Vladavina naroda ili vladavina radnika zahtevala se na svim nivoima i u svim sferama. Jedna od značajnijih kritika koja ima istaknuto mesto među mnogim autorima Praxisa odnosi se upravo na neintegralnu implementaciju radničkog samoupravljanja.

U godini velikih studentskih protesta, Supek navodi da ,ne treba razdvajati radničko i društveno samoupravljanje, to jest direktnu

\footnotetext{
37 Veljko Rus, „Samoupravni egalitarizam i društvena diferencijacija“, PraxisJugoslovensko izdanje 5-6 (1969): 811-827.

38 Vukasović, „Mogućnosti i granice samouopravljanja u kulturi i prosvjeti“, 129-131.

${ }^{39}$ Stojanović, „Sloboda i demokracija u socijalizmu“, 211-212.

40 Svetozar Stojanović, „Od postrevolucionarne diktature do socijalističke demokracije (Jugoslavenski socijalizam na raskršću)“, Praxis-Jugoslovensko izdanje 3-4 (1972): 392.
} 
demokraciju u poduzećima i demokraciju u teritorijalnim i političkim organizacijama koje nazivamo komunama, jer postoji tijesna povezanost između radnih i životnih zajednica koje bi izvjesne modeme neokapitalističke teorije htjele razdvojiti.““1

Stojanović oštro kritikuje tendenciju da se samoupravljanje izjednači sa što većom decentralizacijom i razbijanjem velikih privrednih sistema na veliki broj malih organizacija. ${ }^{42}$ On zahteva jedan ,integralni društveni sistem“ koji će biti sposoban da „obuhvati sve delove društva“ ali i da omogući ,upravljanje društva kao celine sobom.““43

Slično tvrdi i Radivoje Marinković. Samoupravljanje, kaže on, mora biti „ostvarivano kao totalan, integralan društveno-politički proces: kao oblik pomoću kojeg će ljudi sve procese i sveukupno društveno kretanje staviti pod svoju svesnu kontrolu. “44

Nasuprot normativnim idealima ovih autora, u socijalističkoj Jugoslaviji na delu je bila „mešavina etatističke i samoupravne strukture ... samoupravne uglavnom na mikro-nivou. “45

Bez totalnog, integralnog sistema samoupravljanja radnici kao celina ne mogu kontrolisati šire društvene procese:

,ukoliko se samoupravljanje ostvaruje kao parcijalan proces, kao samoupravljanje samo u okviru radne organizacije, komune, mesne zajednice (horizontalno), pomoću njega će se možda ostvarivati uticaj $i$ kontrola nad izolovanim delovima društvenog prostora $i$ aktivnosti, ali će kretanje u celini (vertikalno) ostati izvan njihove kontrole, međusobno neusklađeno, nepovezano, usled čega se ne može uspostaviti ni jedinstvo društva. "46

Ipak, važno je istaći da je problem mnogo ozbiljniji od odsustva same kontrole. Parcijalno radničko samoupravljanje pretvara se $u$

41 Rudi Supek, „Radnički pokret i samoupravljanje“, Praxis-Jugoslovensko izdanje 1-2 (1968): 67.

${ }^{42}$ Stojanović, „Društveno samoupravljanje i socijalistička zajednica“, 683.

${ }^{43}$ Ibid., 682.

44 Radivoje Marinković, „Integralnost samoupravljanja i jedinstvo društva“, Praxis-Jugoslovensko izdanje 3-4 (1971): 502.

45 Stojanović, „Društveno samoupravljanje i socijalistička zajednica“, 684.

${ }^{46}$ Marinković, „Integralnost samoupravljanja i jedinstvo društva“, 502. 
upravljanje nad radništvom. Ovo je suština Supekove kritike iz 1971. godine. On ističe da je radničko samoupravljanje u Jugoslaviji počelo da radi protiv radničke klase. Iako ne kritikuje načela i ideju koja leži u osnovi samoupravljanja, Supek smatra da je glavna greška napravljena kada je implementiran prudonistički model. Empirijsko ostvarenje tog modela opisuje crtama: ,a) pravnog formalizma, b) anti-funkcionalizma u pogledu društvene uloge proizvodnih organizacija, c) buržoaskog liberalizma u odnosu na tržište i samo-regulaciju privrednog razvoja, i d) kombinaciju samoupravne organizacije na horizontalnom nivou $s$ etatističkom strukturom moći na vertikalnom nivou. U cjelini riječ je o jednom shvaćanju koje ostaje u okvirima demokratsko-liberalističke teorije, i koje još nije doprlo do nivoa jedne demokratsko-humanističke i funkcionalističke organizacije proizvođača. “47

$\mathrm{Na}$ ovom tragu Supek kritikuje poslednju privrednu reformu i smatra da je ,pravno i poslovno izjednačavanje proizvodnih i posredničkih organizacija“ imalo izuzetno negativne posledice po radničku klasu. ${ }^{48}$ Tvrdi da su banke, koje nisu podvrgnute društvenom upravljanju, počele eksploatisati proizvodne organizacije. Isključivo tržišna logika samoupravnih posredničnih organizacija onemogućavala je normalnu proširenu reprodukciju, ujednačeniji teritorijalni razvoj, izazvala emigraciju i razbuktala međunacionalne tenzije. Stvoreni su tipično kapitalistički odnosi koji su proizvodili tipično kapitalističke posledice poput bogaćenja jedne klase, raslojavanja, nejednake raspodele, nacionalizma. ${ }^{49}$

Prudonistički model atomizovao je radničku klasu i razbio njenu solidarnost. Partija je imala lični interes da se opredeli za ovakva institucionalna rešenja. S obzirom da je proizvodilo unutrašnje protivrečnosti, radničko samoupravljanje zahtevalo je arbitra. Supek je eksplicitan po pitanju toga ko arbitrira u SFRJ: „Otvoreno valja reći da se iza jugoslavenskog radničkog samoupravljanja krije jedna vertikalna

\footnotetext{
${ }^{47}$ Rudi Supek, „Protivurječnosti i nedorečenosti jugoslavenskog samoupravnog socijalizma“, Praxis-Jugoslovensko izdanje 3-4 (1971): 355.

48 Ibid.

${ }^{49}$ Ibid., 356.
} 
organizacija društvene moći, koju predstavlja Komunistička partija.“50 Partija je, dakle, uvela parcijalno samoupravljanje kako bi zadržala kontrolu nad atomizovanom radničkom klasom, koja se na kraju našla između partijske diktature i eksploatacije od strane finansijskog sektora.

\subsection{Tržišna orijentacija}

Kao što smo videli iz Supekove kritike, parcijalno radničko samoupravljanje omogućilo je prodor tržišnih odnosa. Jedan deo autora upravo je u tržišnoj, robno-novčanoj proizvodnji video najveću prepreku razvoju jugoslovenske socijalističke zajednice. Tako Čaldarović ističe „da je robno-novčana konkurencija jedan od najintenzivnijih oblika alijenacije, da ona u stvari dovodi do najpunije alijenacije čovjeka", te da je „kod nas utoliko drastičnija što se vrši u suprotstavljanju proklamovanim socijalističkim principima i već ostvarenim tekovinama." ${ }^{\text {51 }}$

Čaldarović ispituje tvrdnje zagovornika unutrašnjeg jugoslovenskog tržišta koji u njemu vide „nosioca demokratskih sloboda“, promotera ljudskog ,individualiteta“ i pokretača procesa „debirokratizacije“. 52

Mada priznaje da robno-novčani odnosi zaista mogu doprineti navedenim procesima, tvrdi da se uporedo javljaju i određene negativne posledice koje ne smemo zanemariti. Društvo i preduzeća se atomizuju, zastupaju se isključivo lični interesi, odstupa se od moralno-etičkih podsticaja čime se kvari karakter zajednice. Dodatno, tržišni podsticaji dovode do nejednake razvijenosti različitih delova zemlje i mogu uticati na nacionalna pitanja. Čaldarović se posebno osvrće na sistem nagrađivanja prema radu kao okosnicu tržišne orijentacije. Smatra da je nagrađivanje prema radu naročito neadekvatno u okviru neproizvodnih delatnosti, jer vodi zanemarivanju humanog sadržaja ovih delatnosti.

\footnotetext{
${ }^{50}$ Ibid., 355.

51 Mladen Čaldarović, „Disolucioni procesi u samoupravljanju“, PraxisJugoslovensko izdanje 1 (1965): 76.

52 Ibid., 77.
} 
Tržišna proizvodnja i nagrađivanje prema radu, zaključuje, atomizuju i slabe radničku klasu kao glavnu antibirokratsku snagu čime se postiže suprotan efekat željenom, imajući u vidu da je tržište uvedeno $s$ namerom da oslabi birokratske tendencije. ${ }^{53}$

Šest godina kasnije, Cvjetičanin takođe daje kritiku tržišta, ali se, poput Supeka, usredsređuje na dominaciju finansijskog sektora. Nasuprot autorima koji se zalažu za potpunu deetatizaciju, on smatra da je država previše oslabila tako da ,više ne može efikasno prakticirati svoje funkcije“, a da to nije doprinelo ni samoupravljanju ni socijalizmu. ${ }^{54}$ Umesto da „funkcije raspolaganja sredstvima proširene reprodukcije“ pređu na „udružene proizvođače“, dešava se da „funkcija proširene reprodukcije prelazi na banke i reeksportere kao nove centre otuđene financijske moći.“55

$\mathrm{Na}$ ovom primeru možemo jasno videti suprotstavljena stanovišta među različitim autorima Praxisa. Ona se čak mogu uočiti i kod jednog istog autora u različitim periodima. Naglašavanjem različitih problema i aspekata krize, primećuje se implicitno zalaganje za različite praktično-političke korake. Možda u tome leži najveći doprinos jednodecenijske produkcije Korčulanske letnje škole.

Analizu sam počeo kritikom etatizma $i$ isticanjem nužne potrebe deetatizacije i konačnog odumiranja države, a završavam je upozorenjem na kobne posledice radikalizacije tog stava: „Država u socijalizmu nije samo nužno zlo niti se svako obavljanje nužnih funkcija države može identificirati s etatizmom. To je pseudorevolucionarnost, čiju smo mi cijenu visoko platili. “56

\footnotetext{
${ }^{53}$ Ibid., 78-85.

54 Veljko Cvjetičanin, „Obilježja i dileme samoupravnog jugoslavenskog socijalizma“, Praxis-Jugoslovensko izdanje 3-4 (1971): 597.

55 Ibid.

${ }^{56}$ Ibid., 597-598.
} 


\section{ZAKLJUČAK}

U ovom radu pokušao sam da ukažem na glavne probleme i kritike jugoslovenskog modela radničkog samoupravljanja i delegatske demokratije izložene u jedanaestogodišnjoj produkciji časopisa Praxis. Analizirao sam dvadeset tri teksta koja su u svom naslovu sadržala ili reč „demokratija“ ili reč „samoupravljanje“ u bilo kom obliku. Uočio sam četiri tipa kritika koja možemo okarakterisati kao: 1) etatizam, 2) nedovoljna demokratizacija, 3) neintegralnost samoupravljanja i 4) tržišna orijentacija.

Iz analize se vidi da su određene kritike međusobno usklađene i da se dopunjuju (viši stepen demokratizacije korespondira sa integralnijim sistemom samoupravljanja, dok parcijalno radničko samoupravljanje i tržišna privredna orijentacija dovode do atomizacije i slabljenja radničke klase u celini). Sa druge strane, očigledno je da su neke od njih u pojedinim segmentima prilično suprotstavljene (zahtevi za deetatizacijom i dominacijom privrednih jedinica nasuprot zahtevima za demokratizacijom neophodne političke koordinacije).

Mada je među autorima Praxisa jasno primetan kritički pluralizam, važno je naglasiti da u tekstovima dominiraju leva politička i ideološka uverenja. To je upravo bio i osnovni motiv da se sprovede baš ova vrsta analize. Duboko verujem da današnja globalna politička i ekonomska kriza zahteva levi odgovor i da su nam neophodni modeli koji će narodu (kao demosu) omogućiti veći uticaj na odluke čije posledice direktno osećaju. U vezi sa tim, rekao bih da je smisleno ponovo razmišljati o određenim oblicima direktne ili participativne demokratije i radničkog i društvenog samoupravljanja. Ipak, važno im je pristupiti kritički kako bi se izbegle sve potonje greške i potencijalne opasnosti koje su iz njih proizilazile.

$\mathrm{Na}$ kraju, postavlja se pitanje koliko su tekstovi analizirani u ovom radu zaista relevantni za današnji levi odgovor na krizu. S jedne strane, rekao bih da upozorenja na pogubne posledice tržišnog fundamentalizma i monopolizacije političke moći jesu važna. Sve je više autoritarnih režima, naročito u bivšim državama realsocijalizma, u kojima su politička prava građana na klimavim nogama, dok je u istim 
tim državama slepa vera $u$ neregulisano tržište proizvela velike ekonomske i društvene nejednakosti.

Sa druge strane, analizirani tekstovi nisu posvećivali previše pažnje empirijskim činjenicama i mogućnostima implementacije određenih teorijskih zamisli. Deluje da bi bili znatno relevantniji da su, na tragu Rusovog pristupa, dopuštali revalorizaciju teorijskih zamisli na osnovu nalaza o stvarnom funkcionisanju jugoslovenskog sistema radničkog samoupravljanja.

\section{BIBLIOGRAFIJA}

Bilandžić, Dušan. Historija Socijalističke Federativne Republike Jugoslavije. Zagreb: Školska knjiga, 1976.

Cvjetičanin, Veljko. „Obilježja i dileme samoupravnog jugoslavenskog socijalizma“. Praxis-Jugoslovensko izdanje 3-4 (1971): 595-602.

Cvjetičanin, Veljko. „Odumiranje države kao proces razvoja samoupravljanja u Jugoslaviji“. Praxis-Jugoslovensko izdanje 4-6 (1966): 743-756.

Čaldarović, Mladen. „Disolucioni procesi u samoupravljanju“. PraxisJugoslovensko izdanje 1 (1965): 75-85.

Jakšić, Božidar. „Praxis Gaje Petrovića“. Filozofija i društvo 33 (2007): 73-101. Kanzleiter, Boris, i Stojaković, Krunoslav. „Predgovor“. U Praxis: Društvena kritika i humanistički socijalizam, uredili Dragomir Olujić Oluja i Krunoslav Stojaković, 2-4. Beograd: Rosa Luxembrug Stiftung Southeast Europe, 2012.

Krempton, Ričard Dž. Balkan posle Drugog svetskog rata. Prevela Ksenija Todorović. Beograd: Clio, 2003.

Krešić, Andrija. „Proizvodni principi samoupravljanja“. Praxis-Jugoslovensko izdanje 6 (1971): 827-833.

Lebowitz, Michael. Build it Now: Socialism for the Twenty- First Century. New York: Monthly Review Press, 2006.

Lešaja, Ante. Praksis orijentacija, časopis Praxis $i$ Korčulanska ljetna škola:(građa). Rosa Luxemburg Stiftung Southeast Europe, 2014.

Marinković, Radivoje. „Integralnost samoupravljanja i jedinstvo društva“. Praxis-Jugoslovensko izdanje 3-4 (1971): 501-511.

Matvejević, Predrag. „Requiem za jednu ljevicu“. U Praxis: Društvena kritika $i$ humanistički socijalizam, uredili Dragomir Olujić Oluja i Krunoslav Stojaković, 15-26. Beograd: Rosa Luxembrug Stiftung Southeast Europe, 2012. 
Perović, Milenko A. „Praxis-filozofija“. Arhe 11 (22): 129-138.

Rus, Veljko. „Samoupravni egalitarizam i društvena diferencijacija“. PraxisJugoslovensko izdanje 5-6 (1969): 811-827.

Sekelj, Laslo. Jugoslavija, struktura raspadanja. Beograd: Izdavačko preduzeće Rad, 1990.

Stojanović, Svetozar. „Društveno samoupravljanje i socijalistička zajednica“. Praxis-Jugoslovensko izdanje 5-6 (1967): 680-692.

Stojanović, Svetozar. „Od postrevolucionarne diktature do socijalističke demokracije (Jugoslavenski socijalizam na raskršću)“. PraxisJugoslovensko izdanje 3-4 (1972): 375-398.

Stojanović, Svetozar. „Sloboda i demokracija u socijalizmu“. PraxisJugoslovensko izdanje 2 (1964): 203-213.

Supek, Rudi. „Protivurječnosti i nedorečenosti jugoslavenskog samoupravnog socijalizma“. Praxis-Jugoslovensko izdanje 3-4 (1971): 347-371.

Supek, Rudi. „Radnički pokreti i samoupravljanje“. Praxis-Jugoslovensko izdanje 1-2 (1968): 67-69.

Štefančić, Domagoj. „Promjena naziva Komunističke partije Jugoslavije u Savez komunista Jugoslavije“. Radovi: Radovi Zavoda za hrvatsku povjest Filozofskoga fakulteta Sveučilišta u Zagrebu 39, no. 1 (2007): 259-273.

Tadić, Ljubomir. „Moć, elite i demokratija“. Praxis-Jugoslovensko izdanje 1-2 (1970): 64-77.

Unkovski-Korica, Vladimir. „Samoupravljanje, razvoj i dug: uspon i pad 'jugoslovenskog eksperimenta'“. U Dobro došli u pustinju postsocijalizima, uredili Srećko Horvat i Igor Štiks. 45-74. Zaprešić: Fraktura, 2015.

Vukasović, Ante. „Mogućnosti i granice samoupravljanja u kulturi i prosvjeti“. Praxis- Jugoslovensko izdanje 1-2 (1967): 129-131.

Žvan, Antun. „Etatistički paternalizam ili samoupravljanje“. PraxisJugoslovensko izdanje 6 (1971): 939-947. 


\title{
MILOŠ JANKOVIĆ
}

University of Belgrade, Institute for Philosophy and Social Theory

\section{VIEWS ON DIRECT DEMOCRACY AND SELF-GOVERNMENT FROM THE PERSPECTIVE OF PRAXIS JOURNAL}

\begin{abstract}
The paper analyzes texts of Yugoslav authors to Praxis journal during the eleven years of production. It offers an overview of different views on direct (delegate, participatory) democracy and workers', or social, selfgovernment. Based on different understandings of normative models of direct democracy and self-government, we identified four main lines of criticism that can be characterized as 1) statism, 2) insufficient democratization, 3) nonintegrality of self-government and 4) market orientation. On the one hand, these criticisms complement each other, while on the other hand, they are set against each other.
\end{abstract}

Keywords: direct democracy, self-governing, Praxis

Primljeno: 20.8.2021.

Prihvaćeno: 4.11.2021. 